\title{
Prevalence and characterisation of class 1 and 2 integrons in multi-drug resistant Staphylococcus aureus isolates from pig farms in Chongqing, China
}

\author{
Chao $\mathrm{Ye}^{1}$, Fengqing Hou ${ }^{\dagger}$, Dongyi $\mathrm{Xu}^{1}$, Qingyuan Huang ${ }^{1}$, \\ Xia Chen $^{3}$, Zheng Zeng ${ }^{2}$, Yuanyi Peng ${ }^{1}$, Rendong Fang ${ }^{1 凶}$ \\ ${ }^{1}$ College of Animal Science and Technology, Southwest University, \\ Beibei District, Chongqing, 400715, China \\ ${ }^{2}$ Chongqing Animal Disease Prevention and Control Center, \\ Laboratory of Quality \& Safety Risk Assessment for Animal Products on Biohazards, \\ Ministry of Agriculture, Chongqing 401120, China \\ ${ }^{3}$ Animal Husbandry and Aquatic Products Station of Yubei District, \\ Chongqing 401120, China \\ rdfang@swu.edu.cn
}

Received: March 4, $2020 \quad$ Accepted: August 24, 2020

\begin{abstract}
Introduction: Integrons are mobile DNA elements that allow for acquisition and dissemination of antibiotic-resistance genes among pig farm-derived bacteria. Limited information is available on integrons of Staphylococcus aureus from pig farms. The aim of this study was to characterise and investigate the prevalence of class 1 and 2 integrons in multi-drug resistant (MDR) S. aureus isolates from pig farms. Material and Methods: A total of 724 swabs were collected from 12 pig farms in Chongqing, China, and examined by conventional microbial and molecular methods. Results: In total, 68 isolates were $S$. aureus, 57 of which were methicillin resistant (MRSA). All 68 isolates were MDR strains and carried integrons, of which 88.2\% (60/68) harboured both class 1 and 2 . In addition, $85.3 \%$ (58/68) of the class 2 integron-positive isolates carried the $\beta$-lactam resistance gene (blaTEM-1), and $66.7 \%(40 / 60)$ of the class 1 integron-positive isolates carried the aadAlc, aadAl or $d f r A 1$ gene for respective streptomycin and spectinomycin or trimethoprim resistance. Conclusions: Class 1 and 2 integrons are common among the pig farm-derived $S$. aureus isolates. On account of their significance for public health, the prevalence of the integrons and their associated resistance genes in pig farm-derived $S$. aureus isolates should be paid special attention.
\end{abstract}

Keywords: pig, Staphylococcus aureus, antibiotic resistance, integrons, resistance gene cassettes.

\section{Introduction}

The Staphylococcus species are a group of Grampositive, facultative, aerobic, and unencapsulated bacteria, which are responsible for a variety of skin and tissue infections (23). Of all the species, Staphylococcus aureus (S. aureus) has been most notable as a major human and animal pathogen responsible for a wide variety of infections, including skin infections, pneumonia, bacteraemia, and toxinmediated food poisoning (9). Food poisoning caused by animal-derived $S$. aureus has been one of the most economically important food-borne diseases and a major threat to public health (14). In China, the production and consumption of pork has long been in great demand (20). However, with the increasing abuse of antibiotics on pig farms, multi-drug resistant (MDR) phenotypes of $S$. aureus are emerging and contaminate pork products as a result, which poses a great threat to human health (7).

The bacterial resistance mechanisms involved in the acquisition and spread of resistance genes have been illuminated in the past few years (19). These mainly resolve to one of two types: (i) mutations in preexisting or previously acquired resistance genes, and (ii) horizontal or lateral gene transfer, which is mediated by various types of genetic elements, such as transposons, plasmids, bacteriophages, pathogenicity islands, and integrons $(1,3)$. Among them, integrons are an important mechanism involved in acquisition 
and spreading of antibiotic resistance, which permit tandem integration and expression of various antibioticresistance genes (8).

Integrons contribute to horizontal gene transfer in association with transposons or plasmids. A complete integron is generally composed of three elements: the $5^{\prime}$ conserved segment $\left(5^{\prime} \mathrm{CS}\right)$, an internal variable region containing one or more resistance gene cassettes, and a $3^{\prime}$ conserved segment $\left(3^{\prime} \mathrm{CS}\right)$. The 5'CS contains an integrase gene (intl) that encodes an integrase (recombinase) responsible for site specific insertion of resistance-gene cassettes, a recombination site $(a t t I)$, and a promoter $(\mathrm{Pc})$ that is responsible for expression of the captured gene cassettes. The $3^{\prime} \mathrm{CS}$ contains a quaternary ammonium compound resistance gene $(q a c \Delta E-1)$, the sulphonamide resistance gene (sull) and an open reading frame of unknown function (11). So far, five classes of mobile integrons have been identified and distinguished by differences in the intI sequences. Class 1, 2, and 3 integrons are relatively common and capture from and spread antibioticresistance gene cassettes to the same or other bacterial species by horizontal gene transfer (12). Class 4 and 5 integrons are relatively rare and they are involved in the development of trimethoprim resistance in Vibrio species (12).

Class 1 integrons are the most frequent type in clinical isolates, and most of the reported antibioticresistance gene cassettes are found in this class. Previously, class 1 integrons were identified in a large variety of clinical Gram-negative organisms. Recently, they were observed in a few Gram-positive bacteria as well (21). Although class 2 and 3 integrons have a similar organisation to that of class 1 , they are less detected in bacteria from clinical samples and poorly studied (15). Studies have indicated that Gram-positive bacteria are also a major reservoir of integrons (6). In particular, class 1 integrons have been identified in $S$. aureus isolates from hospitals and cow's milk (11, 24). Class 2 integrons have been identified in $S$. aureus clinical isolates in Tehran, Iran (15).

Pork is a major protein source in the Chinese diet. Pigs are raised on a very large scale in China, and $S$. aureus isolates from pigs are reported to be an important source of methicillin-resistant Staphylococcus aureus (MRSA) (5). To investigate the prevalence of MRSA strains and $S$. aureus isolates carrying class 1 and 2 integrons from pig farms in China, we report here the characterisation of the $S$. aureus isolates from local pig farms in Chongqing.

\section{Material and Methods}

Sample collection. A total of 724 samples were collected from 12 pig farms in 6 regions of Chongqing between November 2018 and January 2019. These samples included faecal swabs $(\mathrm{n}=426)$, floor swabs $(n=215)$, water swabs $(n=22)$, feed swabs $(n=20)$, and air swabs $(\mathrm{n}=41)$, which were randomly collected by the farmers from three pig houses of each farm.

Isolation and identification of $\boldsymbol{S}$. aureus. Each swab was transferred into $15 \mathrm{~mL}$ of buffered peptone water (Land Bridge, China) and incubated at $37^{\circ} \mathrm{C}$ for 16 to $18 \mathrm{~h}$ for recovering $S$. aureus. A loopful of the recovered $S$. aureus suspensions was sub-cultured in $10 \mathrm{~mL}$ of $7.5 \% \mathrm{NaCl}$ broth (Land Bridge) at $37^{\circ} \mathrm{C}$ for 18 to $24 \mathrm{~h}$ and another loopful was streaked onto BairdParker agar plate (Land Bridge) and chromogenic medium (CHROMagar, France), for isolation and direct differentiation, respectively. Finally, the specific genes $f e m B$ and $m e c A$ were used for identifying $S$. aureus and MRSA by PCR and the subsequent DNA sequencing $(13,18)$.

Antibiotic susceptibility testing. Antibiotic susceptibility of all $S$. aureus isolates against 11 subclasses of antimicrobial agents was determined by the Kirby-Bauer disk diffusion method (2) and interpreted according to the Clinical and Laboratory Standards Institute (CLSI) guidelines (4). The tested antimicrobials (Hangzhou Microbial Reagent Co, China) included penicillin (10 U), gentamicin $(10 \mu \mathrm{g})$, tetracycline $(30 \mu \mathrm{g})$, erythromycin $(15 \mu \mathrm{g})$, clindamycin $(2 \mu \mathrm{g})$, trimethoprim/sulphamethoxazole $(25 \mu \mathrm{g})$, chloramphenicol $(30 \mu \mathrm{g})$, ciprofloxacin $(5 \mu \mathrm{g})$, teicoplanin $(30 \mu \mathrm{g})$, rifampicin $(5 \mu \mathrm{g})$, nitrofurantoin $(300 \mu \mathrm{g})$, levofloxacin $(5 \mu \mathrm{g})$, and oxacillin $(1 \mu \mathrm{g})$. Escherichia coli (ATCC25922) was used as a quality control. The $S$. aureus isolates resistant to more than three subclasses of antimicrobial agents were defined as MDR isolates.

Extraction of $S$. aureus plasmid and genomic DNA. The plasmid DNA of $S$. aureus was extracted by using an E.Z.N.A. Plasmid Mini Kit I (Omega Bio-Tek, USA) according to the manufacturer's instructions. The genomic DNA was extracted by the boiling method as previously described (24). Briefly, the overnight cultures of $S$. aureus in $7.5 \% \mathrm{NaCl}$ broth were suspended in $100 \mu \mathrm{L}$ of TE buffer (10 mM Tris; $1 \mathrm{mM}$ EDTA, $\mathrm{pH}$ 8), and then boiled for $10 \mathrm{~min}$, vortexed for $10 \mathrm{~s}$, and finally centrifuged at $9,000 \times \mathrm{g}$ for $5 \mathrm{~min}$. The supernatant containing genomic DNA of $S$. aureus was collected and stored at $-20^{\circ} \mathrm{C}$ until use.

Detection of three classes of integrons. The presence of class 1, 2, and 3 integrons in MDR $S$. aureus was confirmed by PCR amplification of integrase genes (intI1, intI2, and intI3) with their specific primers (Table 1) as described in previous studies (16). PCR mixtures were in the volume of $25 \mu \mathrm{L}$ and PCR amplifications were performed in a T100 thermocycler (Bio-Rad, USA). The reaction conditions for detection of intII were as follows: initial denaturation at $94^{\circ} \mathrm{C}$ for $5 \mathrm{~min}, 35$ cycles of denaturation at $94^{\circ} \mathrm{C}$ for $1 \mathrm{~min}$, annealing at $58^{\circ} \mathrm{C}$ for $30 \mathrm{~s}$, and extension at $72^{\circ} \mathrm{C}$ for $1 \mathrm{~min}$, and a final extension at $72^{\circ} \mathrm{C}$ for $10 \mathrm{~min}$. Conditions for detection of intI2 and intI3 were: initial denaturation at $94^{\circ} \mathrm{C}$ for 5 min, 35 cycles of denaturation at $94^{\circ} \mathrm{C}$ for $1 \mathrm{~min}$, 
annealing at $55^{\circ} \mathrm{C}$ for $30 \mathrm{~s}$, and extension at $72^{\circ} \mathrm{C}$ for $1 \mathrm{~min}$, and a final extension at $72^{\circ} \mathrm{C}$ for $10 \mathrm{~min}$. Furthermore, the two genes located in the $3^{\prime} \mathrm{CS}$ of class 1 integrons conferring resistance to sull and qac $\Delta E-1$ were also confirmed by PCR as protocolled in a previous report (25).

Detection of integron-associated gene cassettes. All integron-positive MDR S. aureus isolates were tested for the presence of internal gene cassettes. The PCR for detecting gene cassette arrays in class 1 integrons employed the primers intll-k and $\ln B$ (Table 1) as previously described (24). The reaction conditions were initial denaturation at $94^{\circ} \mathrm{C}$ for $4 \mathrm{~min}$ and 10 touchdown cycles of denaturation at $94^{\circ} \mathrm{C}$ for $1 \mathrm{~min}$, annealing at $62-53^{\circ} \mathrm{C}$ for $30 \mathrm{~s}$ (decreasing by $1{ }^{\circ} \mathrm{C} /$ cycle) and extension at $72^{\circ} \mathrm{C}$ for $2 \mathrm{~min}$, followed by 24 cycles of denaturation at $94^{\circ} \mathrm{C}$ for $30 \mathrm{~s}$, annealing at $52^{\circ} \mathrm{C}$ for $30 \mathrm{~s}$ and extension at $72^{\circ} \mathrm{C}$ for $2 \mathrm{~min}$, with a final extension at $72^{\circ} \mathrm{C}$ for $7 \mathrm{~min}$. A PCR also detected gene cassette arrays in class 2 integrons. The primers hep 74 and hep51 (Table 1) were used as previously published (25). The reaction conditions were initial denaturation at $94^{\circ} \mathrm{C}$ for $5 \mathrm{~min}, 12$ cycles of denaturation at $94^{\circ} \mathrm{C}$ for $50 \mathrm{~s}$, annealing at $68-57^{\circ} \mathrm{C}$ for $50 \mathrm{~s}$ (decreasing by $1{ }^{\circ} \mathrm{C} /$ cycle) and extension at $72^{\circ} \mathrm{C}$ for $4 \mathrm{~min}$, followed by 30 cycles of denaturation at $94^{\circ} \mathrm{C}$ for $30 \mathrm{~s}$, annealing at $57^{\circ} \mathrm{C}$ for $30 \mathrm{~s}$ and extension at $72^{\circ} \mathrm{C}$ for $4 \mathrm{~min}$, with a final extension at $72^{\circ} \mathrm{C}$ for $5 \mathrm{~min}$.

Cloning, sequencing, and analysis of amplified integron gene cassettes. To analyse the sequences of the gene cassettes, PCR amplicons of the representative cassettes that had a unique size when visualised on the gel were purified with a Gel Extraction Kit (Omega Bio-Tek) and then ligated into the pMD-19T vector (TaKaRa Biomedical Technology, China). After transformation, three positive clones carrying recombinant pMD-19T plasmids were sequenced by the Sanger method. The resulting nucleotide sequences were analysed and compared with the available sequences both in GenBank by the BLAST programme (http://www.ncbi.nlm.nih.gov/blast/) and in the Integron Database (INTEGRALL) (http://integrall.bio. ua.pt/).

Statistical analysis. Comparison of the detection rates of class 1 and 2 integrons between plasmid and genomic DNA was analysed by $\chi^{2}$ test in SPSS software (IBM SPSS, USA). P $<0.05$ was considered statistically significant.

\section{Results}

Prevalence and antibiotic susceptibility of S. aureus isolates. A total of $68 \mathrm{~S}$. aureus isolates were recovered from 724 samples collected on pig farms in Chongqing, which includes 43/426 (10.1\%) from faecal samples, $11 / 215(5.1 \%)$ from floor samples, $3 / 22$ $(13.6 \%)$ from water samples, $6 / 20(30.0 \%)$ from feed samples, and 5/41 (12.2\%) from air samples (Table 2). Of these, $57(83.8 \%)$ isolates were further confirmed as MRSA strains based on the presence of the mecA gene. This gene was contained in 35/43 (81.4\%) isolates from faecal samples, $9 / 11(81.8 \%)$ isolates from floor samples, 2/3 (66.7\%) from water samples, 6/6 (100\%) from feed samples, and $5 / 5(100 \%)$ from air samples (Table 2). Subsequently, 13 antimicrobial agents were used to test the antibiotic susceptibility of the 68 $S$. aureus isolates. It showed that high levels of resistance to antibiotics were found in these isolates. Resistance to penicillin, tetracycline, and erythromycin were observed in all $68 \mathrm{~S}$. aureus isolates. Additionally, $60 / 68(88.2 \%)$ of these isolates were resistant to oxacillin, $46 / 68(67.6 \%)$ to chloramphenicol, 15/68 (22.1\%) to trimethoprim/ sulphamethoxazole, and 7/68 $(10.3 \%)$ to clindamycin. Low resistance rates to rifamycin $(2.9 \%)$, gentamicin $(1.5 \%)$, ciprofloxacin $(1.5 \%)$, levofloxacin $(1.5 \%)$, nitrofurantoin $(0 \%)$, and teicoplanin $(0 \%)$ were noted among the isolates (Table 3).

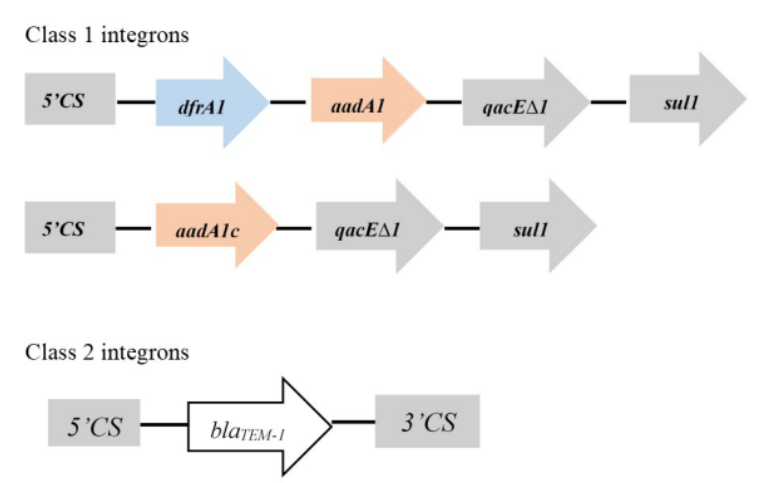

Fig. 1. Schematic representation of the various cassette arrays found in class 1 and class 2 integrons. Arrows display the open reading frames of the different genes. All aadAlc and aadAl genes are represented as orange arrows; $5^{\prime} \mathrm{CS}, 3^{\prime} \mathrm{CS}$, qacE $\Delta 1$, and sull genes as light grey; $d f r A 1$ as light blue; and bla $_{T E M-1}$ genes as white

Detection and characterisation of class 1, 2, and 3 integrons. All the $68 \mathrm{~S}$. aureus isolates were screened with a specific PCR for the presence of class 1,2 , and 3 integrons. Sixty of the 68 isolates $(88.2 \%)$ were positive for class 1 integrons with an amplicon of $280 \mathrm{bp}$, while all 68 isolates had class 2 integrons with an amplicon of $233 \mathrm{bp}$. No class 3 integrons were found in any isolates (data not shown). In addition, there were significant differences in the detection rate of integrons between the bacterial chromosome and plasmid. It was found that in the $S$. aureus isolates, the positive rates for plasmids carrying class 1 and 2 integrons $(88.2 \%$ and $100 \%$, respectively) were significantly higher than those for chromosomes carrying them $(36.8 \%, 45.6 \%$, respectively) (Table 4). Moreover, all integrons on chromosomes were also found on the plasmids of the corresponding $S$. aureus strains (data not shown). 
PCR amplification of the gene cassette indicated that antibiotic-resistance gene cassettes could be detected in $66.7 \%(40 / 60)$ of class 1 integrons and $85.3 \%(58 / 68)$ of class 2 integrons (Table 5). Sequence analysis of the representative PCR amplicons identified several gene cassettes with product sizes of about $700 \mathrm{bp}, 1,200 \mathrm{bp}$ and 2,000 bp (Table 5). In class 1 integrons, three kinds of resistance gene cassette arrays (aadA1c; dfrA1 + aadA1; and aadA1c, dfrA1 + aadA1) were detected in folate pathway inhibitors and aminoglycoside-susceptible isolates (Table 3). Of these, the gene cassette arrays aadAlc (aminoglycosides) and aadAlc, dfrAl + aadAl (aminoglycosides and folate pathway inhibitors) were found to be the most common arrays, which were carried in 25 and 14 class 1 integron-positive isolates, respectively; the $d f r A 1+\operatorname{aadA1}$ array was only found in one class 1 integron-positive isolate. In class 2 integron-positive isolates, only one kind of cassette array $\left(\right.$ bla $\left._{T E M-1}\right)$ related to $\beta$-lactam resistance was observed in 58 class 2 integrons of these isolates (Table 5). For better presentation, a schematic representation of the different cassette arrays found in class 1 and class 2 integrons is shown in Fig. 1.

Table 1. Primers used in this study

\begin{tabular}{|c|c|c|c|}
\hline Primer & Target gene & Sequence $\left(5^{\prime}-3^{\prime}\right)$ & Product size (bp) \\
\hline intll-F & \multirow{2}{*}{ intI-1 } & CCTCCCGCACGATGATC & \multirow{2}{*}{280} \\
\hline intll $1-R$ & & TCCACGCATCGTCAGGC & \\
\hline intI $2-F$ & \multirow{2}{*}{ intI-2 } & TTATTGCTGGGATTAGGC & \multirow{2}{*}{233} \\
\hline intI2-R & & ACGGCTACCCTCTGTTATC & \\
\hline intI3-F & \multirow{2}{*}{ intI-3 } & AGTGGGTGGCGAATGAGTG & \multirow{2}{*}{600} \\
\hline intI3-R & & TGTTCTTGTATCGGCAGGTG & \\
\hline intll-k & \multirow{2}{*}{ variable region 1} & ACCGAAACCTTGCGCTCGT & \multirow{2}{*}{ Variable } \\
\hline $\ln B$ & & AAGCAGACTTGACCTGAT & \\
\hline hon 74 & \multirow{3}{*}{ variable region 2} & CGGGATCCCGGACGGCATGCAC & \multirow{3}{*}{ Variable } \\
\hline nер $/ 4$ & & GATTTGTA & \\
\hline hep 51 & & GATGCCATCGCAAGTACGAG & \\
\hline
\end{tabular}

Table 2. The prevalence of pig farm-derived S. aureus

\begin{tabular}{llll}
\hline Sample sources & $\begin{array}{l}\text { Number of samples } \\
\text { from each source }\end{array}$ & $\begin{array}{l}\text { Number of positive isolates } \\
(\%)\end{array}$ & $\begin{array}{l}\text { Number of MRSA strains among } \\
\text { the positive isolates (\%) }\end{array}$ \\
\hline Faeces & 426 & $43(10.1 \%)$ & $35(81.4 \%)$ \\
Floor & 215 & $11(5.1 \%)$ & $9(81.8 \%)$ \\
Water & 22 & $3(13.6 \%)$ & $2(66.7 \%)$ \\
Feed & 20 & $6(30.0 \%)$ & $6(100 \%)$ \\
Air & 41 & $5(12.2 \%)$ & $5(100 \%)$ \\
Total & 724 & $68(9.4 \%)$ & $57(83.8 \%)$ \\
\hline
\end{tabular}

Table 3. Antibiotic-resistant phenotypes and genotypes of $S$. aureus in this study

\begin{tabular}{|c|c|c|c|c|c|c|}
\hline \multirow{3}{*}{ Antimicrobial subclass } & \multirow{3}{*}{ Antimicrobial agent } & \multicolumn{2}{|c|}{ Phenotypes $(n=68)$} & \multicolumn{3}{|c|}{$\begin{array}{l}\text { Genotypes (number of isolates containing } \\
\text { different resistance gene cassettes) }\end{array}$} \\
\hline & & \multirow{2}{*}{$\begin{array}{l}\text { Number of } \\
\text { resistant } \\
\text { isolates }(\%)\end{array}$} & \multirow{2}{*}{$\begin{array}{l}\text { Number of } \\
\text { sensitive } \\
\text { isolates }\end{array}$} & \multicolumn{2}{|c|}{$\begin{array}{l}\text { Class } 1 \text { integron } \\
(\mathrm{n}=60)\end{array}$} & \multirow{2}{*}{$\begin{array}{l}\begin{array}{l}\text { Class } 2 \text { integron } \\
(\mathrm{n}=68)\end{array} \\
\text { bla }_{T E M-1}\end{array}$} \\
\hline & & & & $\begin{array}{l}\text { aadAlc or } \\
\text { aadA1 }\end{array}$ & $d f r A 1$ & \\
\hline \multirow{3}{*}{$\beta$-lactams } & Penicillin & $68(100)$ & - & - & - & 58 \\
\hline & \multirow{2}{*}{ Oxacillin } & $60(88.2)$ & - & - & - & 50 \\
\hline & & - & 8 & - & - & 8 \\
\hline Tetracyclines & Tetracycline & $68(100)$ & - & - & - & - \\
\hline Macrolides & Erythromycin & $68(100)$ & - & - & - & - \\
\hline \multirow{2}{*}{ Phenicols } & \multirow{2}{*}{ Chloramphenicol } & $46(67.6)$ & - & - & - & - \\
\hline & & - & 22 & - & - & - \\
\hline \multirow{2}{*}{$\begin{array}{l}\text { Folate pathway } \\
\text { inhibitors }\end{array}$} & \multirow{2}{*}{ Trimethoprim-sulfamethoxazole } & $15(22.1)$ & - & - & 2 & - \\
\hline & & - & 53 & - & 12 & - \\
\hline \multirow{2}{*}{ Lincosamides } & \multirow{2}{*}{ Clindamycin } & $7(10.3)$ & - & - & - & - \\
\hline & & - & 61 & - & - & - \\
\hline \multirow{2}{*}{ Rifamycins } & \multirow{2}{*}{ Rifamycin } & $2(2.9)$ & - & - & - & - \\
\hline & & - & 66 & - & - & - \\
\hline \multirow{2}{*}{ Aminoglycosides } & \multirow{2}{*}{ Gentamicin } & $1(1.5)$ & - & 1 & - & - \\
\hline & & - & 67 & 39 & - & - \\
\hline \multirow{4}{*}{ Quinolones } & \multirow{2}{*}{ Ciprofloxacin } & $1(1.5)$ & - & - & - & - \\
\hline & & - & 67 & - & - & - \\
\hline & \multirow{2}{*}{ Levofloxacin } & $1(1.5)$ & - & - & - & - \\
\hline & & - & 67 & - & - & - \\
\hline Nitrofurans & Nitrofurantoin & - & 68 & - & - & - \\
\hline Glycopeptides & Teicoplanin & - & 68 & - & - & - \\
\hline
\end{tabular}


Table 4. Comparison of detection rates of class 1 and 2 integrons in plasmid and genomic DNA in pig farm-derived $S$. aureus

\begin{tabular}{lllll}
\hline Types of DNA & Class 1 integrons & & Class 2 integrons \\
\cline { 2 - 5 } & $\begin{array}{l}\text { Number of positive } \\
\text { (negative) strains }\end{array}$ & $\begin{array}{l}\text { Positive rate } \\
(\%)\end{array}$ & $\begin{array}{l}\text { Number of positive } \\
\text { (negative) strains }\end{array}$ & $\begin{array}{l}\text { Positive rate } \\
(\%)\end{array}$ \\
\hline Genomic DNA & $25(43)$ & 36.8 & $31(37)$ & 45.6 \\
Plasmid DNA & $60(8)$ & 88.2 & $68(0)$ & 100 \\
$\chi^{2}$ & 38.43 & & 50.83 & $<0.001$ \\
P-value & $<0.001$ & & & \\
\hline
\end{tabular}

Table 5. Different types of gene cassette amplicons among the integron-bearing S. aureus

\begin{tabular}{llll}
\hline Types of integrons & $\begin{array}{l}\text { Number of isolates } \\
\text { carrying different cassettes } \\
(\%)\end{array}$ & $\begin{array}{l}\text { Approximate sizes of } \\
\text { amplicon }(\mathrm{bp})\end{array}$ & Inserted cassette(s) \\
\hline \multirow{2}{*}{ Integron 1 } & $25(41.7 \%)$ & 1,200 & aadAlc \\
& $1(1.7 \%)$ & 2,000 & dfrA1 + aadA1 \\
Integron 2 & $14(23.3 \%)$ & $1,200,2,000$ & aadAlc, dfrA1 + aadA1 \\
\hline
\end{tabular}

\section{Discussion}

The prevalence and characterisation of class 1 integrons in Gram-negative bacteria have been well documented; however, the presence of integrons in Gram-positive bacteria has been reported less so far. To our knowledge, this is the first report of the characterisation of class 1 and 2 integrons and their associated gene cassettes in MDR $S$. aureus isolates from pig farms in China. Our data indicated that MDR isolates and the class 1 and 2 integrons were widespread among pig farm-derived $S$. aureus isolates in Chongqing. The most common pattern of the isolates' resistance was insusceptibility to $\beta$-lactams, tetracyclines, and macrolides. In addition, most (83.8\%) MDR isolates were also MRSA isolates.

Unexpectedly, all $S$. aureus isolates were positive for class 2 integrons, and the majority $(88.2 \%)$ of these isolates carried class 1 integrons. However, in previous reports, the proportion of class 1 integrons in $S$. aureus isolates from either farms $(10 \%-25 \%)$ or hospitals $(42.5 \%$ and $53 \%)$ was apparently much lower than that reported here $(17,22,24)$. The proportion of class 2 integrons $(100 \%)$ in this study was also much higher than that $(35.2 \%)$ in $S$. aureus isolates from hospitals in Tehran, Iran (15). This is also the first time that a report is published of class 2 integrons in $S$. aureus isolates from farm animals. The high prevalence of class 1 and 2 integrons in $S$. aureus on pig farms may reflect that the integrons have played an important role in disseminating antimicrobial resistance in bacterial populations.

The class 1 integrons have long been considered the most universal integrons and they have the capability to integrate nearly all the antibiotic-resistance genes, such as those imparting resistance to $\beta$-lactams, aminoglycosides, chloramphenicol and others (12). In our study, we found that only aminoglycoside resistance genes (aadAlc and aadAl) and folate pathway inhibitor resistance determinant $(d f r A l)$ were identified in class 1 integrons. The composition of the resistance gene cassette arrays was simple and only three kinds of arrays (aadA1c; dfrA1 + aadA1; and aadA1c, dfrA1 + aadA1) were observed. However, previous studies have documented many more antibiotic-resistance genes among $S$. aureus isolates from farms or hospitals, such as an assortment of 12 resistance genes ( $\operatorname{hhf} \mathrm{f}, d f r A 1$, dfrA12, aadA1, aadA5, aadA4, aadA24, aacA4, aadA2, $a a d B, c m l A 6$, and $q a c H$ ) found in isolates from Chinese dairy farms (11) or a 10-strong variety of resistance determinants (aadA1, aadA2, aadB, aacA4, dfrA12, oxa2, orfD, orfF, $c a t B 3$, and $c m l A 6$ ) reported in isolates from hospitals $(15,22)$.

Most reported class 2 integrons carry the three specific gene cassettes $d f r A 1$, sat1, and aadA1, which confer resistance to trimethoprim, streptothricin and streptomycin/spectinomycin, respectively $(8,10)$. In this study, only the gene for resistance to $\beta$-lactams, bla $a_{T E M-1}$, was screened in the class 2 integrons of the isolated strains, which had not been reported previously among $S$. aureus strains. It can be seen that the diversity of gene cassettes in class 2 integrons was lower than that in class 1 integrons. The low diversity of integrated gene cassettes in class 2 integrons was probably owing to the non-functional intl 2 generated by the replacement of its internal termination codon with a codon for glutamic acid, which could not excise existing cassettes or insert novel ones (21). In addition, the gene cassettes observed in this study could not correspond to the resistance phenotypes observed (e.g. tetracycline, erythromycin, or chloramphenicol) among the $S$. aureus isolates (Table 3). This suggested that resistance of $S$. aureus to tetracycline, erythromycin, and chloramphenicol may not be associated with integron-mediated antimicrobial resistance. Other resistance mechanisms beyond this research's scope may be responsible for generating these resistant phenotypes. Subsequent genome-wide sequencing analysis will likely elucidate the mechanism for generation of these resistant phenotypes.

This is the first report of the presence and characterisation of class 1 and 2 integrons in 
$S$. aureus isolates from farmed swine in Chongqing, China. The results showed that high occurrence rates $(88.2 \%$ and $100 \%)$ of class 1 and 2 integrons were observed in all $68 \mathrm{~S}$. aureus isolates. Of these, 58 isolates carrying class 2 integrons were positive for the presence of the $\beta$-lactam resistance gene bla TEM- $1_{\text {and }} 40$ isolates carrying class 1 integrons harboured the aadAlc, aadA1 or $d f r A 1$ genes. Out of concerns for public health, the presence of class 1 and 2 integrons and their associated resistance gene cassettes in $S$. aureus isolates from pig farms should be paid special attention and close surveillance of that presence should be mounted.

Conflict of Interests Statement: The authors declare that there is no conflict of interests regarding the publication of this article.

Financial Disclosure Statement: This study was supported by the National Key Research and Development Program of China (2018YFD0500500), the Fundamental Research Funds for the Central Universities (XDJK2019B012, SWU118072), the Chongqing Science \& Technology Commission (cstc2018jscx-msybX0302), the National Agricultural Product Quality and Safety Risk Assessment Project (GJFP2019007), the fund for China Agriculture Research System (CARS-37), and the Beibei Science \& Technology Commission (No. 2018-20). The funding bodies had no role in the study design, data collection or analysis and decision to publish or preparation.

Animal Rights Statement: None required.

\section{References}

1. Alibayov B., Baba-Moussa L., Sina H., Zdeňková K., Demnerová K.: Staphylococcus aureus mobile genetic elements. Mol Biol Rep 2014, 41, 5005-5018.

2. Bauer A.W., Kirby W.M., Sherris J.C., Turck M.: Antibiotic susceptibility testing by a standardized single disk method. Am J Clin Pathol 1966, 45, 493-496.

3. Boerlin P., Reid-Smith R.J.: Antimicrobial resistance: its emergence and transmission. Anim Health Res Rev 2008, 9, $115-126$.

4. Clinical and Laboratory Standards Institute: M02 Performance standards for antimicrobial disk susceptibility tests, $13^{\text {th }}$ ed. CLSI, Wayne, 2018.

5. Cui S., Li J., Hu C., Jin S., Li F., Guo Y., Ran L., Ma Y.: Isolation and characterization of methicillin-resistant Staphylococcus aureus from swine and workers in China. J Antimicrob Chemother 2009, 64, 680-683.

6. Deng Y., Liang Y., Cui H., Zhao X., Zhong N., Li Y., Chen D., Bian H., Li Y., Yu G.: Roles of integrons in the antimicrobial resistance of Gram-positive microorganisms. Rev Med Microbiol 2015, 26, 26-31.

7. Guo D., Liu Y., Han C., Chen Z., Ye X.: Phenotypic and molecular characteristics of methicillin-resistant and methicillinsusceptible Staphylococcus aureus isolated from pigs: implication for livestock-association markers and vaccine strategies. Infect Drug Resist 2018, 11, 1299-1307.
8. Hansson K., Sundström L., Pelletier A., Roy P.H.: IntI2 integron integrase in Tn7. J Bacteriol 2002, 184, 1712-1721.

9. Hardy K.J., Hawkey P.M., Gao F., Oppenheim B.A.: Methicillin resistant Staphylococcus aureus in the critically ill. Br J Anaesth 2004, 92, 121-130.

10. Labbate M., Case R.J., Stokes H.W.: The integron/gene cassette system: an active player in bacterial adaptation. Methods Mol Biol 2009, 532, 103-125.

11. Li L., Zhao X.: Characterization of the resistance class 1 integrons in Staphylococcus aureus isolates from milk of lactating dairy cattle in Northwestern China. BMC Vet Res 2018, $14,59$.

12. Mazel D.: Integrons: agents of bacterial evolution. Nat Rev Microbiol 2006, 4, 608-620.

13. Mehrotra M., Wang G., Johnson W.M.: Multiplex PCR for detection of genes for Staphylococcus aureus enterotoxins, exfoliative toxins, toxic shock syndrome toxin 1, and methicillin resistance. J Clin Microbiol 2000, 38, 1032-1035.

14. Miao J., Chen L., Wang J., Wang W., Chen D., Li L., Li B., Deng Y., Xu Z.: Current methodologies on genotyping for nosocomial pathogen methicillin-resistant Staphylococcus aureus (MRSA). Microb Pathog 2017, 107, 17-28.

15. Mostafa M., Siadat S.D., Shahcheraghi F., Vaziri F., JaponiNejad A., Vand Yousefi J., Rajaei B., Harifi Mood E., Ebrahimzadeh N., Moshiri A., Seyed Siamdoust S.A., Rahbar M.: Variability in gene cassette patterns of class 1 and 2 integrons associated with multi drug resistance patterns in Staphylococcus aureus clinical isolates in Tehran-Iran. BMC Microbiol 2015, 15, 152.

16. Moura A., Henriques I., Ribeiro R., Correia A.: Prevalence and characterization of integrons from bacteria isolated from a slaughterhouse wastewater treatment plant. J Antimicrob Chemother 2007, 60, 1243-1250.

17. Nandi S., Maurer J.J., Hofacre C., Summers A.O.: Gram-positive bacteria are a major reservoir of class 1 antibiotic resistance integrons in poultry litter. Proc Natl Acad Sci USA 2004, 101, 7118-7122.

18. Paterson G.K., Larsen A.R., Robb A., Edwards G.E., Pennycott T.W., Foster G., Mot D., Hermans K., Baert K., Peacock S.J., Parkhill J., Zadoks R.N., Holmes M.A.: The newly described mecA homologue, mecA LGA251, is present in methicillin-resistant Staphylococcus aureus isolates from a diverse range of host species. J Antimicrob Chemother 2012, 67, 2809-2813.

19. Stalder T., Barraud O., Casellas M., Dagot C., Ploy M.C.: Integron involvement in environmental spread of antibiotic resistance. Front Microbiol 2012, 3, 119.

20. Wang H., Wang T., Luo Q., Huo X., Wang L., Liu T., Xu X., Wang Y., Lu F., Lun Z., Yu L., Shen J.: Prevalence and genotypes of Toxoplasma gondii in pork from retail meat stores in Eastern China. Int J Food Microbiol 2012, 157, 393-397.

21. Xu Z., Li L., Shi L., Shirtliff M.E.: Class 1 integron in Staphylococci. Mol Biol Rep 2011, 38, 5261-5279.

22. Xu Z., Li L., Shirtliff M.E., Peters B.M., Li B., Peng Y., Alam M.J., Yamasaki S., Shi L.: Resistance Class 1 integron in clinical methicillin resistant Staphylococcus aureus strains in southern China, 2001-2006. Clin Microbiol Infect 2011, 17 714-718.

23. Xu Z., Shi L., Alam M.J., Li L., Yamasaki S.: Integron-bearing methicillin-resistant coagulase-negative staphylococci in South China, 2001-2004. FEMS Microbiol Lett 2008, 278, 223-230.

24. Xu Z., Shi L., Zhang C., Zhang L., Li X., Cao Y., Li L., Yamasaki S.: Nosocomial infection caused by class 1 integroncarrying Staphylococcus aureus in a hospital in South China. Clin Microbiol Infect 2007, 13, 980-984.

25. Zhang H., Shi L., Li L., Guo S., Zhang X., Yamasaki S., Miyoshi S., Shinoda S.: Identification and characterization of class 1 integron resistance gene cassettes among Salmonella strains isolated from healthy humans in China. Microbiol Immunol 2004, 48, 639-645. 